\title{
硬膜外腔に発生した結核腫の一例
}

\begin{tabular}{|c|c|c|c|c|c|}
\hline 福 & 島 & 一 & 彦・奥 & 江 & \\
\hline 高 & 妻 & 雅 & 和 石 & 崎 & 知 \\
\hline 松 & $\square$ & 信 & 行・白 & 沢 & 建 \\
\hline 松 & 永 & 英 & 裕 & & \\
\hline
\end{tabular}

\section{A Case of Intraspinal Extradural Tuberculoma}

by

\section{K. Fukushima, A. Okue, M. Kouzuma, T. Ishizaki,} K. Shirasawa and E. Matsunaga

Orthopaedics Surgery, Saga Prefectural Hospital

We have experienced an intraspinal extradural tuberculoma in a 51-year-old man who had pain in low back and lower limbs. These symptoms disappeared after removal of the tumor by laminectomy. This tumor was pathologically examined to be a tuberculoma.

\section{はじめに}

今日，結核性疾患は減少したとは言え，今なお珍し い疾患ではない，当科に拈いては，過去 6 年間に 18 例を見たが，乙のうち10 例は胸部レ線所見に異常を 認めず，結核菌を証明できたのは，わずかに2 例であ った．今回我々は，近年では極めて稀な硬膜外腔に発 生した結核腫の一例を経験したので，乙こに報告す る.

症例

症例： 51 才, 男性, 漁業

主訴：腰痛および両下肢痛

家族歴：父母, 兄弟, 親族に結核の既往なし

既往歴：特記すべきととなし

現病歴：昭和 57 年 1 月より腰痛を覚え, 同 年 4 月 に右大腿部および左下腿部痛も加わったため, 近医に て骨盤牽引をしてあらうも軽快せず，同年 5 月当科に 入院する.

入院時所見：全身所見に 異常なく，局所所見で， $\mathrm{L}_{3}, \mathrm{~L}_{4}, \mathrm{~L}_{5}$ の手掌圧痛陽性, 右慰部圧痛点陽性, Lasegue は右 $70^{\circ}$ にて陽性, 下肢腱反射は左右アキレ
ス腱反射および左膝蓋腱反射が消失し, 両足部の知覚 異常を認めたが, 筋力低下と膀胱直腸障害は認めなか った. 検查所見：血沈は 1 時間值 $6 \mathrm{~mm}$; 2 時間值 $13 \mathrm{~mm}$ と正常であり, 血液, 尿所見も正常であった. 胸写でも, 結核を疑わせる所見を認めなかった。

䯣液検査では, 初圧 $130 \mathrm{mmH}_{2} \mathrm{O}$, 終圧 $105 \mathrm{mmH}_{2}$ O, Queckenstedt は陽性, 細胞数は $14 / 3$, 糖量は $60 \mathrm{mg} / \mathrm{dl}$ と正常であったが, 蛋白量は $210 \mathrm{mg} / \mathrm{dl}$ と 上昇し，グロブリン反応で Pandy (十）であり，春 髄腔の閉塞所見が得られた。

ペリドログラムにて, $\mathrm{L}_{3}$ 椎体中央より造影剂の上 行が得られ難く, 硬膜外腔での後方からの圧迫が想定 された（図 1 -A). 次いで行った後頭下穿刺による ミエログラムでは, $\mathrm{L}_{3}, \mathrm{~L}_{4}$ で完全停止像を示した（図 $1-\mathrm{B})$.

以上より，硬膜外腔腫湯を疑い，手術にふみきっ た.

手術所見: $\mathrm{L}_{3}, \mathrm{~L}_{4}$ の椎弓切除を行ったが, 骨には 異常なく, $\mathrm{L}_{3}, \mathrm{~L}_{4}$ の硬膜外腔のやや左側に, 縦約 1.5 $\mathrm{cm}$, 横約 $1.0 \mathrm{~cm}$ の黄白色の腫瘤が存在しており, 左 $\mathrm{L}_{4}$ ルートを压迫していた（図 2). 腫瘤は硬膜と 癒着していたため, ッッペルにて剝離したところ, 途 

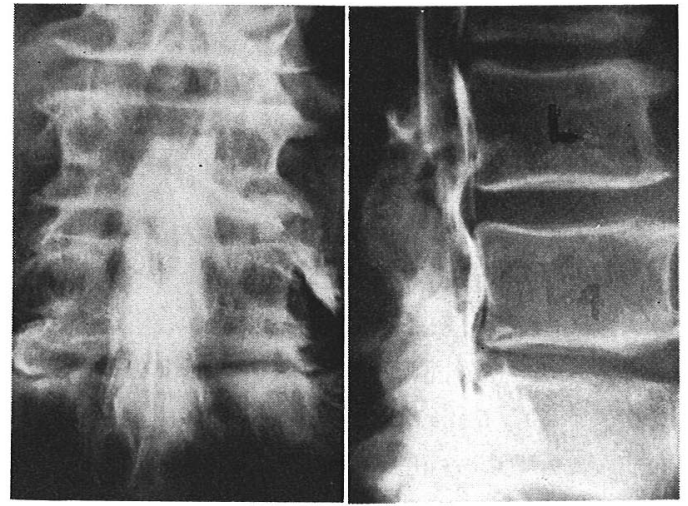

(A) ペリドログラム: $\mathrm{L}_{3}$ 中央上り造影剤の上 行が得られ難加った。
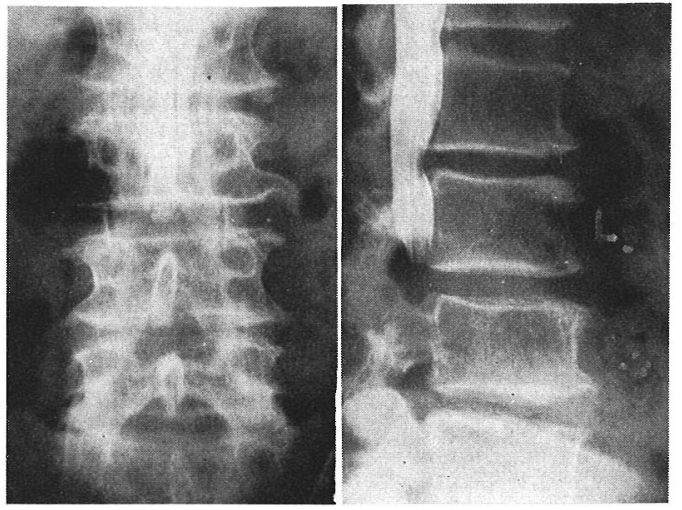

（B）ミエログラム： $\mathrm{L}_{3}, \mathrm{~L}_{4}$ で完全停止像を示 した。

\section{図 1}

中で腫溜が破れ，白い膿瘍物質が流出した。

病理所見：腫瘤は中心に凝固壊死を有し，それを Langhans 型巨細胞や異型巨細胞を 混じた好酸球様 類上皮細胞が取り囲み，その周囲を小リンパ球や形質 細胞が取り囲んだ曲型的な結核性肉芽腫と診断された (図 3 ).

術後経過：術後の結核に関しての検索では,ッベル クリン反応は陽性であったが，喀痰検査，胸部断層に ては異常を認めなかった。

術後, 腰痛掞よび下肢の症状は, 間もなく消失し, 6 力月間に及ぶ抗結核剂 3 者併用療法を行ない，その 後元気に社会復帰している.

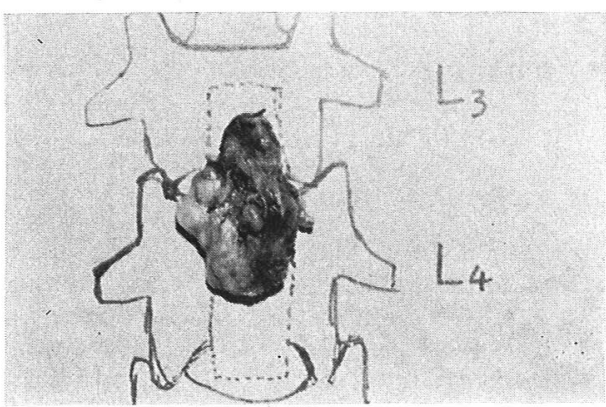

図2摘出された腫瘤; 緃約 $1.5 \mathrm{~cm}$ ，横約 $1.0 \mathrm{~cm}$ で, 左 $\mathrm{L}_{4}$ ルートを压迫していた.

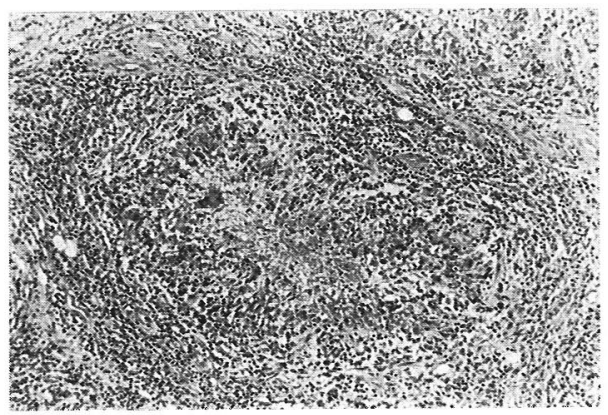

図3病理組織標本; 中心に凝固壞死る有し, そ れをLanghans 型巨細胞を混じた好酸球 様類上皮細胞が取り囲んでいる。(H.E. メ 400)

$$
\text { 考察 }
$$

脊髄に発生する肉芽腫の鑑別疾患としては，1）黄 色ブドウ球菌，連鎖球菌，緑膿菌なごの感染による肉 芽腫 2) ゴム腫 3) 真菌症 4) 住血吸虫症 5) 結核腫などが考えられる ${ }^{17}$ 。

また，下肢の麻暆を起こす脊髄結核腫を，Griffiths ら ${ }^{8)}$ は, 以下の如く 5 種類示した.

1) Tubelculosis of the verteblae with compression of the cord due to abscess formation, granulation tissue, or bony displacemet.

2) Tubelculous extradural granulation tissue without evidence of tuberculous disease of bone, causing compression of the spinal cord or cauda equina.

3) Vascular thrombosis, due to endarteritis of the radicular arteries, producing ische- 


\section{表 1}

（A）脊䯣結核腫の，諸外国での報告例

\begin{tabular}{|c|c|}
\hline \multicolumn{2}{|l|}{ SPINAL TUBERCULOMA } \\
\hline \multicolumn{2}{|l|}{ 1830: Sérre, F. R. A. et al. } \\
\hline 1971: Rao, S. B. et al16). & $($ India $) *$ \\
\hline 1971: Waleszkowski, J. et al. ${ }^{19)}$ & (Poland) \\
\hline 1972: Dastur, H. M.4) & (India) \\
\hline 1972: Kak, V. K. et al. ${ }^{13)}$ & ain)* \\
\hline 1974: Dinakar, I. et a1.6) & (India) \\
\hline 1975: Burgielski, R. et al.2) & (Poland)* \\
\hline 1976: Chandrasoma, P. T. ${ }^{3)}$ & (India) \\
\hline 1976: Hirose \& Shimazaki ${ }^{10)}$ & $(J a p a n) *$ \\
\hline 1977: Tsuruta, Saito \& Takeda ${ }^{18)}$ & (Japan) \\
\hline 1979: Norman, C. H. Jr. et al.15) & (U.S.A.) \\
\hline 1981: Reichenthal, E. et al.17) & (U.S.A2* \\
\hline 1981 : Hirasawa \& Kumakura et al.9 & (Japan) \\
\hline 1982: Nakamura \& Takase ${ }^{14)}$ & (Japan) \\
\hline \multicolumn{2}{|l|}{ (*: Spinal Extradural Tuberculoma) } \\
\hline (B) 脊嗔結核腫の, 本邦て & \\
\hline
\end{tabular}

SPINAL TUBERCULOMA (JAPAN)

1259: Iwanaga ${ }^{11}$

1967: Izumida \& Ikeda12)

1976: Hirose \& Shimazaki*

1977: Tsuruta, Saito \& Takeda

1981: Hirasawa \& Kumakura et al.

1982: Nakamura \& Takase

(*: Spinal Extradural Tuberculoma)

mia of the spinal cord.

4) Intramedullary tuberculoma.

5) Tuberculous arachnoiditis, as a result of tuberculdus meningitis causing paraplegia.

我々の症例は，2）の骨病変を伴わない結核性肉芽 組織による圧迫に相当する。

脊䯣結核腫は，諸外国では，1830 年 Sérre により 初めて報告され，1957 年までに 171 例の報告がある が9，以後抗結核剂の普及により激减した。1970 年以 降, 我々が知り得た症例は 13 例であり, 硬膜外腔 の あのは 5 例である（表 $1-\mathrm{A}$ ).

本邦では, 1925 年岩永ら ${ }^{11)}$ により初めて報告され, 1967 年までに 15 例, うち硬膜外腔のあのは 10 例 ${ }^{22}$ であるが，そ机以降，我々が知り得た報告は 5 例であ り，うち硬膜外腔のあのは本症例合わせ 2 例である (表 $1-\mathrm{B}$ ).

当科では, 1976 年から 1982 年の間に, 以下の如き 18 例の結核性疾患を経験している.
1. Tuberculous Spondylitis

$$
8 \text { (C: 1, Th: 3, Th-L: 1, L:3) }
$$

2. Tuberculous Arthritis

4 (Elbow: 1, Ster.-clav.: 1, Hip: 1, Knee: 1)

3. Tuberculous Osteomyelitis

2 (Femur: 1, Rib: 1)

4. Others (Soft part)

a) Tuberculous Tenosynovitis

1 (Dorsum of the Hand)

b) Tuberculous Lymphadenitis 1 (Axilla)

c) Tuberculous Abscess

1 (Distal part of the Thigh)

d) Tuberculoma

1 (Lumbar Epidural Space)

これらのうち 4 例のみが活動性, 他に 4 例が非活動 性の肺病変の所見を呈しており, 残りの 10 例 では, 全く胸部の異常を認めず, さらに, 18 例中結核菌を証 明し得たのは，わずかに 2 例であった．乙れは近中の 結核性疾患の特徵をあらわしているとも言え, 慢性炎 症性疾患の㟝断では，常々結核を念頭に置か秝ばなら ないと思っている.

さて，本症例の発生因であるが，骨羅患なく，胸部 にあ異常を認めなかったため, 恐らく結核菌の気道感 染ののち, 血行性に菌が企播し，たまたま硬膜外腔に ひっかかり，そてで結核腫を形成したのであろうと考 えている.

$$
\text { ま と め }
$$

比較的稀な, 硬膜外腔結核腫 の 治療経験 を報告し た. 症状は, 椎弓切除下の腫瘤摘出にて消失し, これ につづく半年間の抗結核剤投与にて，再発などを見る ととなく,よく治療に反応した。

\section{文献}

1) Arseni, C., Samita, D. C. T.: Intraspinal tuberculoma granuloma, Brain, 83 : 285, 1960.

2) Burgielski, R., Lechowski, S.: Epidural tuberculoma of the spinal canal, Gruzlica, May: 507-508, 1975.

3) Chandrasoma, P. T.: Intramedullarycord tuberculoma presenting glioma, Neurol In- 
dia, 24-3: 164-166, 1976.

4) Dastur, H. M.: A tuberculoma review with some personal experiences, Neurol India, 20-3: 127-131, 1972.

5) Decker, H. G., Shapiro, S. W. et al.: Epidural tuberculous abscess simultating herniated lumbar intervertebral disk, Ann. Surg., 149: 294-296, 1959.

6) Dinakar, I. : Intramedullary tumors of spinal cord, Indian J. cancer, 8-4: 292296, 1971.

7) Dunn, C. R., Kelly, W. A. et al.: Spinal epidural neoplasia, J. Neurosurg., 52: 4751, 1980.

8) Griffith, D. L., Seddon, H. J. et al.: Potts paraplegia, London : Oxford University Press, 1956.

9）平沢秀人, 態倉徹雄, et al.: 脊䯣結核腫の一 例. 臨床神経学, 21-10: 845-847, 1981.

10）広瀬源二郎，嶋崎鋼兵：硬膜外結核腫による横 断性脊䯣炎の 1 例. 日内会誌, 65：299, 1976.

11）岩永仁雄：脊䯣坬立性結核腫の手術的治験。実 地医家と臨床，2：839，1925.

12）泉田重雄, 池田 彬：春髄腫瘍のまとめ（自家
93例を中心に), 外科, 29: 412, 1967.

13) Kak, V. K.: Epidural Spinal tuberculoma presentings as "spinal tumor syndrome", Tubercle, 53-2: 139-142, 1972.

14）中村, 高瀬：結核性脊随膜炎治療後に結核腫が 見い出された 1 例. 内科, 49-3: 557-560, 1982.

15) Norman, C. JR.: Intramedullary tuberculoma of the spinal cord, J. NATL Med. Assoc., 71-3: 231-232, 1979.

16) Rao, S. B., Dinakar, I. et al.: Extraosseous extradural tuberculous granuloma simultating a herniated lambar disk, J. Neurosurg., 35: 488-490, 1977.

17) Reichenthal, E., Cohn, M. L. et al.: Extraosseus extradural tuberculous granuloma of the cervical spine, Surgical Neurology, 15-3: 178-181, 1981.

18）鶴田潤介，斉藤孝次，et al.：極めて稀な脊㵦 結核腫の一治験例。臨床神経学, 17-11: 767, 1977.

19) Walszkowski, J., Rydzewski, W.: Isolated tuberculoma in the spinal canal, Neurol Neurochir Pol., Nov-Dec: 877-880, 1971. 